\title{
Non-Edible Plant Oils as New Sources for Biodiesel Production
}

\author{
Arjun B. Chhetri ${ }^{1}$, Martin S. Tango ${ }^{1,2}$, Suzanne M. Budge ${ }^{1}$, K. Chris Watts ${ }^{1}$ and \\ M. Rafiqul Islam ${ }^{1, *}$
}

1 Faculty of Engineering, Dalhousie University, 1360 Barrington Street, Halifax NS B3J 2X4, Canada

2 School of Engineering, Acadia University, Wolfville, NS, Canada

E-Mails: kcarjun@dal.ca (A. C.); martin.tango@acadiau.ca (M. T.); budges@dal.ca (S. B.); chris.watts@dal.ca (K.W.); rislam@dal.ca (M. I.)

*Author to whom correspondence should be addressed; E-Mail: rislam@dal.ca; Tel. +1.902.4943980

Received: 5 December 2007 / Accepted: 28 January 2008 / Published: 8 February 2008

\begin{abstract}
Due to the concern on the availability of recoverable fossil fuel reserves and the environmental problems caused by the use those fossil fuels, considerable attention has been given to biodiesel production as an alternative to petrodiesel. However, as the biodiesel is produced from vegetable oils and animal fats, there are concerns that biodiesel feedstock may compete with food supply in the long-term. Hence, the recent focus is to find oil bearing plants that produce non-edible oils as the feedstock for biodiesel production. In this paper, two plant species, soapnut (Sapindus mukorossi) and jatropha (jatropha curcas, L.) are discussed as newer sources of oil for biodiesel production. Experimental analysis showed that both oils have great potential to be used as feedstock for biodiesel production. Fatty acid methyl ester (FAME) from cold pressed soapnut seed oil was envisaged as biodiesel source for the first time. Soapnut oil was found to have average of $9.1 \%$ free FA, $84.43 \%$ triglycerides, $4.88 \%$ sterol and $1.59 \%$ others. Jatropha oil contains approximately $14 \%$ free FA, approximately $5 \%$ higher than soapnut oil. Soapnut oil biodiesel contains approximately $85 \%$ unsaturated FA while jatropha oil biodiesel was found to have approximately $80 \%$ unsaturated FA. Oleic acid was found to be the dominant FA in both soapnut and jatropha biodiesel. Over 97\% conversion to FAME was achieved for both soapnut and jatropha oil.
\end{abstract}

Keywords: biodiesel, petrodiesel, non-edible plant oils, soapnut, jatropha curcas L., sustainability 


\section{Introduction}

The use of edible vegetable oils and animal fats for biodiesel production has recently been of great concern because they compete with food materials. As the demand for vegetable oils for food has increased tremendously in recent years, it is impossible to justify the use of these oils for fuel use purposes such as biodiesel production. Moreover, these oils could be more expensive to use as fuel. Hence, the contribution of non-edible oils such as jatropha and soapnut will be significant as a nonedible plant oil source for biodiesel production.

Jatropha is grown in marginal and waste lands with no possibility of land use competing with food production. Pant et al. [1] showed that jatropha oil content varies depending on the types of species and climatic conditions, but mainly on the altitude where it is grown. The study showed that the average oil contents in jatropha curcas L. at the elevation ranges of 400-600m, 600-800m and 800$1000 \mathrm{~m}$ were $43.19 \%, 42.12 \%$ and $30.66 \%$ of their seed weight respectively. Manian and Gopalakrishan [2] reported similar findings that there was a dominate utilization of photo assimilation for plant growth compared to oil production at the higher altitudes. In the present study, the jatropha seeds were collected from the elevation range of $1200-1400 \mathrm{~m}$.

Soapnut is reported to be wildly grown in forests areas in Nepal in the elevation of 300-1900m [3]. It is reported that $S$. mukorossi species of soapnut grows wild from Afganistan to China, ranging in altitudes from 200 to $1500 \mathrm{~m}$ in regions where precipitation varies from 150 to $200 \mathrm{~cm} /$ year [4]. For this study, the soapnut seeds were collected from the elevation of $1300 \mathrm{~m}$ where average annual rainfall is $150 \mathrm{~cm} /$ year. The plant grows very well in deep loamy soils and leached soils so cultivation of soapnut in such soil avoids potential soil erosion. The soapnut tree can be used for multiple applications such as rural building construction, oil and sugar presses, and agricultural implements among others. Hence, integration of soapnut plantation along with community forestry would help to produce more seeds as potential sources to the biodiesel feedstock.

In this paper, soapnut and jatropha both collected from Nepal are presented as a source for biodiesel production. For the first time, soapnut has been investigated as a potential source for biodiesel. The uses of non-edible plant oil sources are particularly important as the issue of competition of biodiesel feedstock with food products has drawn serious attention in the society.

\section{Description of Plant Sources for Biodiesel Feedstock}

\subsection{Soapnut (Sapindus mukorossi)}

Soapnut is a fruit of the soapnut tree generally found in tropical and sub-tropical climate areas in various parts of the world including Asia, America and Europe. Two main varieties (S. mukorossi and S. trifoliatus) are widely available in India, Nepal, Bangladesh, Pakistan and many other countries. Ucciani et al. [5] reported that the oil content in $S$. trifoliatus which is very similar to $S$. mukorossi seed kernels, was on average $51.8 \%$ of seed weight. The oil from soapnut has been considered a nonedible oil having significant potential for biodiesel production from the material which otherwise is a waste material. Figure 1 and 2 are the soapnut tree showing fruit, seed, seed shell and the kernel. 
Figure 1. Soapnut tree (Haryana-online.com, 2007) Figure 2: Soapnut fruit, seed, seed shell and kernel.
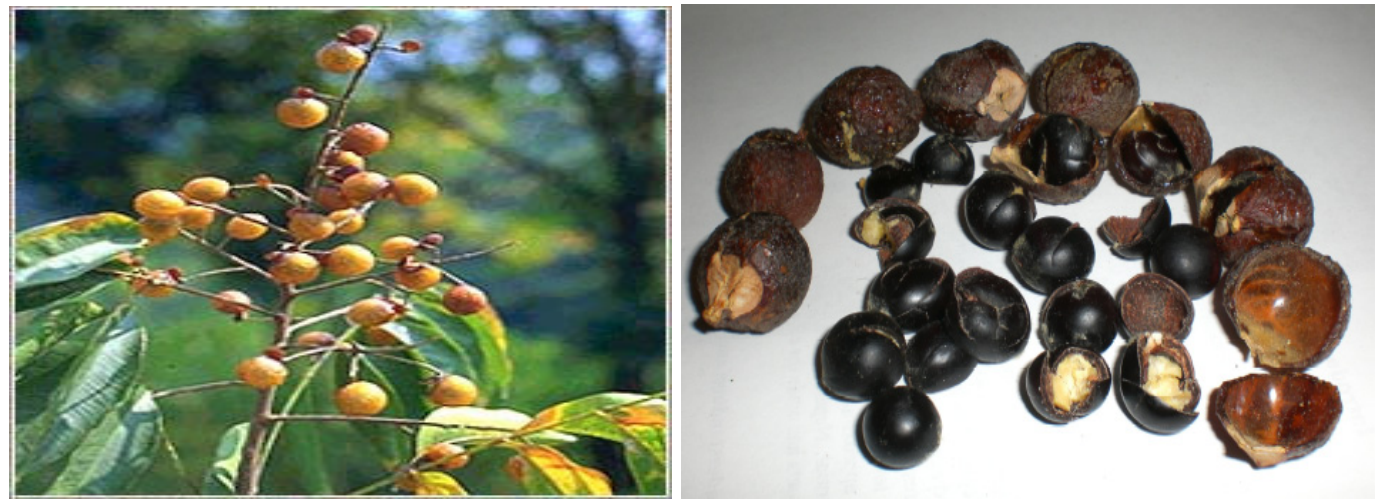

Chhetri et al. [6] carried out a comprehensive study on the uses of various parts of the soapnut tree. Soapnut has several applications from medicinal treatments to soap and surfactant. Soapnut fruit shells have been in use as natural laundry detergents from ancient times for washing fabrics, bathing and traditional medicines. Mandava [7] reported that saponins from Soapnut shells can be used for treatment of soil contaminants. Several other studies also showed that soapnut has a great potential as a natural surfactant for washing the soils contaminant with organic compounds [8;9]. The recorded external use of saponin does not cite any toxic effects on human skin and eyes [10]. These application all make use of the pericarp shell and the seeds are usually waste. Hence, the use of soapnut seeds as a biodiesel source becomes the "waste-to-energy" scheme. Furthermore, planting soapnut trees in community forestry and in barren lands provides sink for carbon sequestration as well as feedstock for biodiesel production.

Olsen [3] reported that the total value of exports of soapnut as medicinal use including other four species made up to $52 \%$ of the total non timber forest products export to India from Nepal. The totals of 32 non-timber forest products are exported with a total value of 8.1 million US dollar for the year $1997 / 1998$. Recently it was reported that the glycerol, a by-product of biodiesel production, can be used to produce organic acids such succinic acids by bacterial fermentation [11]. Hence, the economics of biodiesel from soapnut oil can easily be realized on community scale as it can be integrated in the community forestry plan.

\subsection{Jatropha (jatropha curcas L.)}

Jatropha curcas $L$. is a plant belonging to Euphorbiaceae family that produces a significant amount of oil from its seeds. This is a non-edible oil-bearing plant widespread in arid, semi-arid and tropical regions of the world. Jatropha is a drought resistant perennial tree that grows in marginal lands and can live over 50 years [12]. The oil content in jatropha seed is reported to be in the ranges from 30 to $50 \%$ by weight of the seed and ranges form 45 to $60 \%$ weight of the kernel itself [13]. The jatropha tree has several beneficial properties such as its stem is being used as a natural tooth paste and brush, latex from stem is being used as natural pesticides and wound healing, its leaf as feed for silkworms among other uses (Chhetri et al., 2007). It is a rapidly growing tree and easily propagated. Figure 3 shows the 
jatropha planted in Nepal (locally called 'Sajiwan' which is translated as 'long life') as a living fence to protect crops, its fruits and the oil-bearing seed.

Jatropha usually grows below 1400 meters of elevation from sea level and requires a minimum rainfall of $250 \mathrm{~mm}$, with an optimum rainfall between $900-1200 \mathrm{~mm}$ (Bosswell, 2003) [12]. This plant is not even browsed by animals for its leaves. Recently J. curcas is being considered as one of the most promising potential oil source to produce biodiesel in Asia, Europe and Africa. Chhetri et al. [14] elsewhere discussed the multiple use of jatropha for different purposes. Among other parts of the jatropha tree, the seed has so far been found appropriate for numerous uses.

Figure 3. Jatropha planted as living fence, its fruit and seed from Nepal [15].

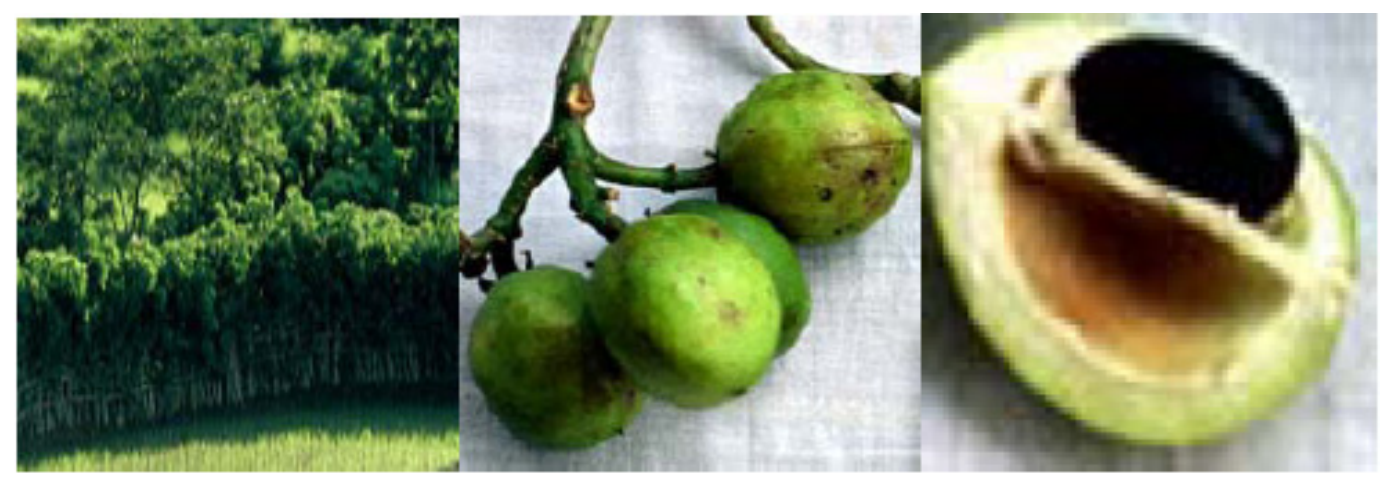

Several studies have shown that there exists an immense potential for the production of plant based oil to produce biodiesel. Azam et al. [16] studied the prospects of fatty acid methyl esters (FAME) of some 26 non-traditional plant seed oils including jatropha to use as potential biodiesel in India. Among them, Azadirachta indica, Calophyllum inophyllum, J. curcas and Pongamia pinnata were found most suitable for use as biodiesel and they meet the major specification of biodiesel for use in diesel engine. Moreover, they reported that 75 oil bearing plants contain $30 \%$ or more oil in their seed, fruit or nut. Subramanian et al. [17] reported that there are over 300 different species of trees which produce oil bearing seeds. Thus, there is a significant potential for non-edible oil source from different plants for biodiesel production as an alternative to petrodiesel.

\section{Materials and Methods}

Soapnut seeds (S. mukorossi) were collected from Nepal. The kernels were separated from the shells for oil extraction. The kernels were then cold pressed and approximately 1.5 grams of oil was recovered from 5 grams of kernels for duplicate samples (30\% oil content). Similarly jatropha seeds collected from Nepal were cold pressed in "Sundhara Oil Expeller" at the Research Centre for Applied Science and Technology (RECAST) laboratory in Tribhuwan University, Nepal. From 1000 grams of jatropha seed, approximately 278 grams of oil (27.8\%) was recovered. Because only the cold press method was used for oil extraction, the oil content recorded here is comparatively less than reported in the literature. Some oil might have been lost in the expeller. Chemical extraction could enhance oil recovery.

For both of these oils, acid catalyzed transesterification with $\mathrm{H}_{2} \mathrm{SO}_{4}$ in methanol $(0.5 \mathrm{~N})$ was used to produce FAME [18]. FAME were characterized using gas chromatography (GC) with flame ionization 
detection (FID) using a 50\% cyanopropyl polysiloxane phase (Agilent Technologies, DB-23; $30 \mathrm{~m} \mathrm{x}$ $0.25 \mathrm{~mm}$ ID). Helium was used as the carrier gas and the gas line was equipped with an oxygen scrubber. The following temperature program was employed: $153{ }^{\circ} \mathrm{C}$ for $2 \mathrm{~min}$, hold at $174{ }^{\circ} \mathrm{C}$ for 0.2 min after ramping at $2.3{ }^{\circ} \mathrm{C} \mathrm{min}-1$ and hold at $220{ }^{\circ} \mathrm{C}$ for 3 min after ramping at $2.5{ }^{\circ} \mathrm{C}$ min-1. FAME were reported as weight percent of total FA. Each FA was described using the shorthand nomenclature of $\mathrm{A}: \mathrm{Bn}-\mathrm{X}$, where A represents the number of carbon atoms, $\mathrm{B}$ the number of double bonds and $\mathrm{X}$ the position of the double bond closest to the terminal methyl group.

Lipid class composition was determined using thin-layer chromatography with FID on the IATROSCAN TH-10 Analyzer MKIII. Each biodiesel sample was dissolved in chloroform and applied to a chromatod. The chromarods were then developed in a tank containing a 48:48:4:1 hexane:petroleum ether:diethyl ether:formic acid solvent system for 25 minutes. After developing they were oven dried and then scanned until just after the phospholipid peak Lipids were identified by comparison of retention times to that of pure standards. Data were analyzed with Peak Simple Chromatography software and area percent, uncorrected for differential response of lipids, was used to calculated lipid content as weight percent of total. This technique was used to determine the free fatty acid content and oil to methyl ester conversion for soapnut and jatropha oil.

\section{Experimental Results}

\subsection{Biodiesel (FAME) from soapnut oil}

Soapnut oil was found to have $9.1 \%$ free FA, $84.43 \%$ triglycerides, $4.88 \%$ sterol and $1.59 \%$ others. Over $97 \%$ ester yield was achieved. Biodiesel produced from the transesterification of soapnut oil was analyzed to determine FA composition. The FA of biodiesel produced from soapnut oil obtained by GC is presented in Table 1.

Table 1. FA content of the methyl esters from soapnut oil.

\begin{tabular}{lcc}
\hline \multicolumn{1}{c}{ FA } & Structure* & Amount (\%) \\
\hline Palmitic acid & $16: 0$ & 4.67 \\
Patmitoleic acid & $16: 1$ & 0.37 \\
Stearic acid & $18: 0$ & 1.45 \\
Oleic acid & $18: 1$ & 52.64 \\
Linoleic acid & $18: 2$ & 4.73 \\
Alpha or gamma-linolenic acid & $18: 3$ & 1.94 \\
Arachidic acid & $20: 0$ & 7.02 \\
Eicosenic acid & $20: 1$ & 23.85 \\
Behenic acid & $22: 0$ & 1.45 \\
Erucic acid & $22: 1$ & 1.09 \\
Lignoceric acid & $24: 0$ & 0.47 \\
Others & & 0.32 \\
Total & & 100.00 \\
\hline
\end{tabular}

*Note: Carbon number with 'zero' double bonds are saturated fatty aids, with 'one' double bonds are monosaturated and with 'two' and 'three' double bonds are polyunsaturated FA. 


\subsection{Biodiesel from Jatropha Oil}

Jatropha oil contains approximately $14 \%$ free FA [19]. It was found that over $97 \%$ ester conversion was achieved after acid catalyzed transesterification. The FA composition of biodiesel produced from jatropha oil is presented in Table 2 .

Table 2. FA analysis of jatropha oil biodiesel.

\begin{tabular}{llll}
\hline FA & Content & Amount (\%) & \% as reported by Gubitz et al. [20] \\
\hline Lauric acid & $12: 0$ & 0.31 & \\
Palmitic acid & $16: 0$ & 13.38 & $14.1-15.3$ \\
Patmitoleic acid & $16: 1$ & 0.88 & $0-1.3$ \\
Stearic acid & $18: 0$ & 5.44 & $3.7-9.8$ \\
Oleic acid & $18: 1$ & 45.79 & $34.3-45.8$ \\
Linoleic acid & $18: 2$ & 32.27 & $29.0-44.2$ \\
Others & & 1.93 & others \\
Total & & 100 & \\
\hline
\end{tabular}

\section{Discussion}

Oleic acid was the most common FA found in both soapnut and jatropha oil derived biodiesel products. Soapnut oil biodiesel was found to have 52.63\% oleic acid (18:1), 23.84\% eicosenic acid (20:1), 7\% arachidic acid (20:1), 4.73\% linoleic acid (18:2) and 4.67\% palmitic acid (16:0). Approximately $85 \%$ of the FA found in soapnut biodiesel were unsaturated.

Jatropha biodiesel was found to contain $45.79 \%$ oleic acid (18:1), 32.27\% linoleic acid (18:2), 13.37\% palmitic acid (16:0) and 5.43\% stearic acid (18:0). Palmitic and stearic acid are the major saturated FA found in jatropha oil biodiesel. It contains approximately $80 \%$ unsaturated FA.

Allen (1998) summarized the FA composition of some naturally occurring oils and fats (Table 3). It is observed that the oleic acid content in soapnut oil $(\sim 52 \%)$ is comparable with the oleic acid content in peanut oil (53-71\%), palm oil (38-52\%), corn oil (19-49\%) and tallow (40-50\%). However, the palmitic acid content is comparable only with peanut oil (6-9\%), rapeseed oil (1-3\%) and sunflower oil (3-6\%). The stearic acid content is comparable with all oils listed in Table 3 except tallow which contains 14-29\% stearic acid. Eicosenic acid is absent in most of the oils in Table 3 except for rapeseed oil. However, the amount of Eicosenic acid found in soapnut oil biodiesel was significantly higher $(23.84 \%)$ than in the rapeseed oil (4-12\%).

Similarly, the oleic acid content in jatropha oil biodiesel (45.79\%) was comparable with peanut oil (53-71\%), corn oil (19-49\%) and tallow (40-50\%). The linoleic acid content (32.27\%) was similar with that of peanut oil (13-27\%) and corn oil (34-62\%). The amount of palmitic acid content (13.79\%) found was similar corn oil (8-12\%). Jatropha biodiesel has a stearic acid content (5.43\%) similar to all natural oils summaried in the Table 3 except tallow. The overall fatty acid content in jatropha biodiesel was comparable with the results reported by Gubitz et al. [20]. 
Table 3. FA composition of some naturally occurring oils/fats [21].

\begin{tabular}{llllllll}
\hline \multirow{2}{*}{ FA } & \multicolumn{2}{c}{ Carbon } & \multicolumn{2}{l}{$\%$ composition of Oil/Fat } \\
& number & PNO & RSO & CRO & PO & SUO & TLO \\
\hline Lauric & - & - & - & - & - & - & Tr-0.2 \\
Myristic & $14: 0$ & $\operatorname{tr}-1$ & - & Tr-.7 & $0.5-6$ & & $2-8$ \\
Palmitic & $16: 0$ & $6-9$ & $1-3$ & $8-12$ & $32-45$ & $3-6$ & $24-37$ \\
Stearic & $18: 0$ & $3-6$ & $0.4-3.5$ & $2-5$ & $2-7$ & $1-3$ & $14-29$ \\
Arachidic & $20: 0$ & $2-4$ & $0.5-2.4$ & $\operatorname{tr}$ & $\operatorname{tr}$ & $0.6-4$ & $\operatorname{Tr}-1.2$ \\
Behenic & $22: 0$ & $1-3$ & $0.6-2.1$ & $\operatorname{tr}$ & - & $\operatorname{Tr}-0.8$ & - \\
Palmitoleic & $16: 1$ & Tr-1.7 & $0.2-3$ & $0.2-1.6$ & $0.8-1.8$ & $\operatorname{Tr}$ & $1.9-2.7$ \\
Oleic & $18: 1$ & $53-71$ & $12-24$ & $19-49$ & $38-52$ & $14-43$ & $40-50$ \\
Eicosenic & $20: 1$ & - & $4-12$ & - & - & - & - \\
Erucic & $22: 1$ & - & $40-50$ & - & - & - & - \\
Linoleic & $18: 2$ & $13-27$ & $12-16$ & $34-62$ & $5-11$ & $44-75$ & 1.5 \\
Linolenic & $18: 3$ & - & $7-10$ & $\operatorname{tr}$ & $\operatorname{tr}$ & $\operatorname{tr}$ & - \\
\hline
\end{tabular}

Note:PNO-Peanut Oil; RSO-Rapeseed Oil; CRO-Corn Oil; PO-Palm Oil; SUO-Sunflower Oil and TLO-Tallow.

The amount and type of FA in the biodiesel determines the viscosity, one of the most important characteristics of biodiesel. Due to the presence of higher amount of long chain FA, soapnut oil may have a slightly higher viscosity compared to jatropha oil. Due to the presence of similar FA, jatropha oil biodiesel has similar viscosity to that of peanut oil, corn oil, palm oil and sunflower oil.

Jatropha is considered as one of the mainstream alternatives for biofuel development. $J$. curcas is a multipurpose species with many attributes and considerable potential. Reddy and Ramesh (2005) [22] reported the comparison of properties of diesel, jatropha oil and biodiesel from jatropha (Table 4). Biodiesel produced from jatropha oil has similar characteristics as that of petroleum diesel which shows that jatropha oil is a strong alternative for the diesel replacement.

Table 4. Comparison of properties of diesel, neat jatropha oil and biodiesel [22].

\begin{tabular}{lccc}
\hline Properties & Diesel & Neat jatropha oil & Biodiesel from jatropha \\
\hline Density $\left(\mathrm{kg} / \mathrm{m}^{3}\right)$ & 840 & 918 & 880 \\
Viscosity $(\mathrm{cSt})$ & 4.59 & 49.9 & 5.65 \\
Calorific value $(\mathrm{kJ} / \mathrm{kg})$ & 42390 & 39774 & 38450 \\
Flash point $\left({ }^{0} \mathrm{C}\right)$ & 75 & 240 & 170 \\
Cetane number & $45-55$ & 45 & 50 \\
Carbon residue & 0.1 & 0.44 & Not available \\
\hline
\end{tabular}

Hanna et al. [23] reported that new and large markets for biodiesel demand are expected to emerge in China, India and Brazil. A recent report indicated that more than 1.3 million farmers in three counties of the provinces Guizhou, Sichuan and Yunnan in southwest China have started to produce jatropha for biodiesel production. The cultivation area of the J. curcas tree in the three counties was 
reported to be 26,667 hectares in 2007 and the figure will exceed 266,670 hectares by 2012 which promises an increase in annual income from 62.5 to 87.5 US dollars for each working household [24]. The jatropha seed is particularly suitable for biodiesel production because it can be harvested in the third year of plantation five or six times annually. India has also taken similar initiative to produce jatropha biodiesel. The Ministry of Non-conventional energy planned to produce jatropha in 3.1 million hectares by 2008-2009 that would save Rs 95 billion equivalent of foreign currency each year from jatropha tree oil [25]. The total production of biodiesel is considered approximately 3 million tons annually at the rate of 0.94 tons per hectare. Production of non-edible oil has been the main focus in both these countries. Hence, development of environmentally friendly biofuel from non-edible oils such as soapnut and jatropha has great promise to the energy economy of developing, as well as developed countries.

Brazil's diesel consumption is 40 billion liters per year, providing huge opportunities for biodiesel production, and it is expected that the biodiesel market will be approximately 2 billion liters by 2013 [26]. According to the USDA [27], biodiesel represents the biggest biofuel, accounting for approximately $82 \%$ of the total biofuel production in the Europe Union (EU). The EU has adopted regulations stating that after $2005,2 \%$ of the total market share should be supplemented by biofuels, including ethanol and biodiesel, whereas the total market share to be maintained by 2010 is $5.7 \%$ [28]. EU governments have set a target for 2020 that at least $10 \%$ of the road fuels should be contributed from biofuels [29]. The US is projected to be the largest biodiesel market by 2010, accounting for about $18 \%$ of the world's biodiesel market [30]. Various provinces of Canada have adopted renewable energy portfolio standards. For example, the province of Nova Scotia has proposed regulations that stipulate that $5 \%$ of the total power generation will be met by renewable sources by 2010 [31].

Goldemberg [32] summarized job creation by different energy sources including renewable sources (Table 5). Biomass such as wood energy and ethanol from sugarcane has significantly higher job requirements compared to other energy sources. It has also been argued that biodiesel production requires a greater number of jobs than bioethanol production. Moreover, the environmental impact associated with greenhouse gas emission is significantly lower due to the extraction of $\mathrm{CO}_{2}$ by plants.

Table 5. Jobs in Energy Production [32]

\begin{tabular}{|c|c|}
\hline Sector & Jobs (person-years)/TWh \\
\hline Petroleum & 260 \\
\hline Offshore oil & 265 \\
\hline Natural gas & 250 \\
\hline Coal & 370 \\
\hline Nuclear & 75 \\
\hline Wood energy & 1000 \\
\hline Hydro & 250 \\
\hline Minihydro & 120 \\
\hline Wind & 918 \\
\hline Photovoltaics & 7600 \\
\hline Ethanol (from sugarcane) & 4000 \\
\hline
\end{tabular}

Khan et al. [33] carried out a sustainability analysis of some community-based energy projects including biodiesel and showed that the total output from a biodiesel system in terms of energy output, 
environmental and socio-economic impacts are positive. The sustainability of a biodiesel system was tested against the set criteria for environmental, economical and social sustainability [34;35;36]. The total change in the environmental capital $\left(\mathrm{Cn}_{\mathrm{t}}\right)$ after the introduction of biodiesel is considered to be higher $\left(\frac{d C n_{t}}{d t} \geq 0\right)$ than before the introduction of the system. The environmental benefits include lower emission of pollutants including $\mathrm{CO}_{2}, \mathrm{CO}$, NOx, particulates, air toxics and sulfur, and $\mathrm{CO}_{2}$ sequestration in the plants. Creation of a higher number of jobs during feedstock production, value addition of glycerin to pharmaceutical products, and production of a high value meal from the seed cake for poultry and animals would make biodiesel economically beneficial in the long-term. Hence, the total changes in economic capital $\left(\mathrm{Ce}_{\mathrm{t}}\right)$ due to the introduction of biodiesel can not be negative $\frac{d C e_{t}}{d t} \geq 0$

) thus satisfying the economic sustainability criteria. Moreover, introduction of biodiesel helps prevent the importing of fossil fuels, results in lower health cost due to an improved environment, and offers energy security and a higher economic opportunities. This all contributes to a positive effect in the total social capital $\left(\mathrm{Cs}_{\mathrm{t}}\right)$ fulfilling the criteria for social sustainability $\left(\frac{d C s_{t}}{d t} \geq 0\right.$ ). Contrasting these benefits, biodiesel could have negative environmental and social aspects, such as the loss of catalysts in glycerol and waste wash water, higher effluent treatment cost, and competition with food items. These can be improved by recovering and recycling the catalysts and using waste and nonedible oil as feedstock for biodiesel production. The economics of biodiesel can further be enhanced by developing a community based approach especially in developing countries [37]. Hence, development of biodiesel from non-edible plant sources not only provides energy alternatives but also provides several environmental and economic benefits.

\section{Conclusions}

Soapnut (Sapindus mukorossi) oil and $j$ curcas oil collected from Nepal were investigated as nonedible oil sources for the production of biodiesel. Our results showed that both oils have great potential to use as feedstock for biodiesel production, owing mainly to their high oil content. Based on GC analysis, eleven types of FA were identified and quantified in soapnut biodiesel. Approximately $85 \%$ of the FA were found to be unsaturated. Similarly, six major FA were identified and quantified in jatropha oil biodiesel, of which approximately $80 \%$ were unsaturated. Soapnut oil was found to have approximately $9.1 \%$ free FA, $84.43 \%$ triglycerides and $4.88 \%$ sterol. Jatropha oil contained approximately $14 \%$ free FA. Over 97\% conversion to FAME was achieved for both soapnut and jatropha oil. Biodiesel from soapnut and jatropha have been concluded to be potential environmentfriendly sources for alternate transportation fuel.

\section{Acknowledgement}

The first and last authors would like to acknowledge NSERC discovery grant for funding this research. The authors would like to thank Anne Timmins for her assistance during the laboratory process. 


\section{References}

1. Pant, K.S.; Kumar, D.; Gairola, S. Seed oil content variation in jatropha curcas L. in different altitudinal ranges and site conditions in H.P. India. Lyonia 2006, 11, 31-34.

2. Manian, K.; Gopalakrishan, S. Physiological basis for ecological preference of Eucalyptus globulus Labill (blue gum) - II Growth and Oil production. Indian Forester 1995, 121, 300-305.

3. Olsen, C.S. A qualitative assessment of the sustainability of commercial non-timber forest product collection in Nepal. Forestry discussion paper 12, Royal Veterinary and Agricultural University, Copenhagen, 1997; pp. 30.

4. Haryana-online.com, 2007. Ritha. http://www.haryana-online.com/Flora/ritha.htm (Accessed on October 14, 2007)

5. Ucciani, E.; Mallet, J.F; Zahra, J.P. Cyanolipids and fatty acids of Sapindus trifoliatus L. (Sapindaceae) Seed Oil. Fat Science Technology 1994, 96, 2, 69 - 71.

6. Chhetri, A.B.; Pokharel, Y.R.; Mann, H and Islam, M.R. Characterization of soapnut and its use as natural additives. Int. Journal of Material and Products Technology, 2007a, accepted, July.

7. Mandava, S.S. Application of a natural surfactant from sapindus emerginatus to in-situ flushing of soils contaminated with hydrophobic organic compounds. M.S. Thesis in Civil and Environmental Engineering, Faculty of Louisiana State University and Agricultural and Mechanical College, 1994.

8. Roy, D.; Kommalapati, R.R.; Mandava, S.; Valsaraj, K.T.; Constant, W.D. Soil washing potential of a natural surfactant. Environ. Sci. Technol. 1997, 31(3), 670-675.

9. Kommalapati, R.R.; Valsaraj, K.T.; Constant, W. D.; Roy, D. Soil flushing using colloidal gas aphron suspensions generated from a plant-based surfactant. Journal of Hazardous Materials 1998, 60, 73-87.

10. Windholz, M. The Merck Index: An Encyclopedia of Chemicals, Drugs, and Biologicals; Merck: Rathway, NJ, 1983.

11. Song, H.; Lee, S.Y. Production of succinic acid by bacterial fermentation. Enzyme and Microbial Technology 2006, 39, 352-361.

12. Bosswell, M.J. Plant Oils: Wealth, health, energy and environment. In Proc. International conference of Renewable Energy Technology for rural Development, Kathmandu, Nepal, Oct 1214, 2003.

13. Pramanik, K. Properties and use of jatropha curcas oil and diesel fuel blends in compression ignition engine, Renewable Energy 2003, 28, 239-248.

14. Chhetri, A. B.; Islam, P.; Mann, H. Zero-waste multiple uses of jatropha and dandelion. J. Nat. Sci. and Sust. Tech. 2007, 1, 75-99.

15. The Kathmandu Post. Nepal/UK Oil Seed Project, 2001. http://freespace.virgin.net/ himal.proj/theseshimal.htm; Project background (Accessed on October 14, 2007)

16. Azam, M. M.; Waris, A.; Nahar, N.M. Prospects and potential of fatty acid methyl esters of some non-traditional seed oils for use as biodiesel in India. Biomass and Bioenergy 2005, 29, 293-302.

17. Subramanian, A.K.; Singal, S.K.; Saxena M.; Singhal, S. Utilization of liquid biofuels in automotive diesel engines: An Indian perspective. Biomass and Bioenergy 2005, 9, 65-72. 
18. Budge, S. M.; Iverson, S. J.; Koopman, H. N. Studying trophic ecology in marine ecosystems using fatty acids: A primer on analysis and interpretation. Marine Mammal Science, 2006, 22, 759-801.

19. Tiwari, A.K.; Kumar, A.; Raheman, H. Biodiesel production from Jatropha oil (Jatropha Carcus) with high free fatty acids: an optimized process. Biomass and Bioenergy 2007, 31, 569-575.

20. Gubitz, G.M.; Mittelbach, M.; Trabi, M. Exploitation of the tropical oil seed plant. Jatropha curcas L. Bioresource Technology 1999, 67, 73-82.

21. Allen, C.A.W. Prediction of biodiesel fuel atomization characteristics based on measured properties. Ph.D. Thesis, Faculty of Engineering, Dalhousie University, 1998; pp. 200.

22. Reddy, J.N and Ramesh, A. Parametric studies for improving the performance of a Jatropha oilfuelled compression ignition engine. Renewable Energy 2005, 31, 1994-2016.

23. Hanna, M.A.; Isom, L.; Campbell, J. Biodiesel: current perspectives and future. Journal of Scientific and Industrial Research 2005, 64, 854-857.

24. People daily online. Green technology to alleviate poverty in western China, 2006 http://english.people.com.cn/200611/22/eng20061122_324040.html (Accessed on November 22, 2006).

25. Srivastava, S. 'Wonder plant' to fuel India. AsiaTimesonline. South Asia, May 18, 2006. www.atimes.com/atimes/South_Asia/HE18Df05.html (Accessed on May 20, 2006)

26. Pousa, G.P.A.G.; Santos, A.L.F.; Suarez, P.A.Z. History and policy of biodiesel in Brazil. View Point. Energy Policy 2007, (in press).

27. USDA, United States Department of Agriculture, Production Estimates and Crop Assessment Division Foreign Agricultural Service. EU-25 oilseeds and products biofuels situation in the European Union. Prepared by: Karin Bendz, Global Agriculture Information Network (GAIN) Report, 2005.

28. Hansen, A.C.; Zhang, Q.; Lyne, P.W.L. Ethanol-diesel fuel blends-a review. Bioresour. Technol. 2005, 96, 277-85.

29. Crooks, E. and Harvey, F. Harsh realities impinge on early promise. http://search.ft.com/ftArticle?ct=0\&id=070619010217\&x=0, Jun 19, 2007 (Accessed on August $15,2007)$.

30. Demirbas, A. Importance of biodiesel as transportation fuel. Energy Policy 2007, 35, 4661-4670.

31. Canada Renewable Energy Alliance, 2006. Green power for electricity generation-creating an industry in Canada. Energy efficiency and conservation: The cornerstone of a sustainable energy future.

32. Goldemberg, J. Renewable energy: regional potentials and priorities. The Johannersburg Renewable Energy Coalition1st International Conference in Brussels, Jun 4, 2003.

33. Khan, M.I.; Chhetri, A.B.; Islam, M.R. Analyzing sustainability of community-based energy technologies, Energy Sources 2007, (in press).

34. Pokharel, G.R.; Chhetri, K.C.; Khan, M.I.; Islam, M.R. En Route to strong sustainability: Can Decentralized community owned micro hydro energy systems in Nepal realize the Paradigm? A case study of Thampalkot VDC in Sindhupalchowk district in Nepal; Presentation at International Conference on Renewable Energy Technology for Rural Development, Kathmandu, Nepal, Nov 12-14, 2003. 
35. Khan, M.I.; Islam, M.R. True Sustainability in technological development and natural resources management; Nova Science Publishers: New York, USA, 2007; pp. 384.

36. Chhetri, A. B.; Islam, M.R. Inherently sustainable technology development; Nova Science Publishers: New York, USA, 2007; (in press).

37. Chhetri, A. B.; Islam, M.R. Towards producing a truly green biodiesel. Energy Sources 2007, (in press).

(C) 2008 by MDPI (http://www.mdpi.org). Reproduction is permitted for noncommercial purposes. 